\title{
LEVERAGE EMERGING TREND OF E-VEHICLE - RESPONSE OF PASSENGER CAR USER
}

\author{
Dr. Uma Maheswari Sankar \\ Department of Commerce, PSG College of Arts and Science, Coimbatore, India \\ Dr. S. Gokilavani \\ Department of Commerce, Kristu Jayanti College, Bengaluru, India \\ Major Dr R Rajasekaran \\ Department of Commerce, PSG College of Arts and Science Coimbatore, India
}

\begin{abstract}
Governments all over the globe world are implementing policies to push electric vehicles to scale back dependence on oil, decrease greenhouse emission emissions, and improve air quality. The early market growth for electric vehicles continues, but the range of barriers prevents their more widespread uptake. These barriers include the extra cost of the new technology, the relative convenience of the technology considering range and charge times, and consumer understanding about the supply and viability of the technology. The growth of electric vehicle markets is primarily tied to eventual consumers' general awareness and acceptance of the prospective payback of electric vehicles. Governments at national and native levels, automobile manufacturers and dealers, electric utilities, and other groups are occupied in numerous tricks that were used to create consumer understanding about electric vehicles. This study has been taken to understand dealers' and customer awareness and willingness for the e-vehicle in the automobile industry more specifically with the passenger car market. The present research is a descriptive study, primary data and secondary data has been used. Objectives were framed, research design prepared, required data have been collected and suitable analysis was made
\end{abstract}

Key words: E-vehicle, awareness, willingness, market, customers, dealers

Cite this Article: Uma Maheswari Sankar, S. Gokilavani and R Rajasekaran, Leverage Emerging Trend of E-Vehicle- Response of Passenger Car User, International Journal of Management, 11(12), 2020, pp. 3166 -3176.

http://iaeme.com/Home/issue/IJM?Volume $=11 \&$ Issue $=12$ 


\section{INTRODUCTION}

The world's fifth-largest auto market is geared up for a stunning transformation moving completely towards electric vehicles (EVs) by 2030. This is part of the Honourable Prime minister Narendra Modi government's vision to helm a renewable-energy revolution in the country. The present government expects that the automobile sector's massive conversion will cut its oil bill, reduce emissions and curb the up-coming demand for road infrastructure for the next 12 years. Many of our cities are among the World's most polluted, suffering utter degradation over the years and vehicular pollution is one of the major causes for air pollution. India imports $82 \%$ of fossil fuel and India is the Asia's third-largest country imports oil. The Government of India acknowledge the pressure to look at sustainable mobility solutions to reduce dependency on imported energy sources, reduce Green House Gases (GHG) emissions and mitigate adverse impacts from transportation. The present India's road transport minister Nitin Gadkari said "We should move towards alternative fuel...I am getting to do that, whether you wish it or not, "shift to alternative fuels and technologies including bio fuels, electric vehicles, and overall system efficiency of infrastructure.

The National Electric Mobility Mission Plan (NEMMP 2020) was announced recently to incentivize use and production of electric vehicles (EVs) in India with a view to diminish adverse environmental impacts of vehicles and to enhance energy security. The electricity that powers your EV can come from many sources, which include low-emission sources like gas and 0 emission sources like wind, solar, hydro, and atomic power, which enable EVs to dramatically reduce gaseous emissions. In this context EVs are expected to play a significant role in low carbon transition of India and it will be large impact for the future passenger car market. A. First Indian electric car was launched in 2001 by REVA, a Bengaluru-based company. Back then, it cost Rs250,000 per unit. (Mumbai-based Mahindra bought over REVA and renamed it Mahindra Electric - it remains the sole electric passenger vehicle-maker in India.) "We believe the auto industry and makers are willing to form this alteration since most of those have electric platforms ready," However, it's going to not be a simple ride. For one, confining long-term battery provisions and rising A battery management system technology that helps recharge batteries are sturdy.

\subsection{Electric Vehicle}

India's first electric car was launched in 2001 by REVA, a Bengaluru-based company. Back then, it cost Rs250,000 per unit. (Mumbai-based Mahindra bought over REVA and renamed it Mahindra Electric - it remains the only electric passenger vehicle-maker in India.) Since then, except for 2016 when the segment saw 36\% growth to 22,000 units, including four- and twowheelers, the EV industry has been subdued. On Sept. 14, 2017. Suzuki, the parent firm of India's largest car-maker, Maruti Suzuki, announced its plan to set up a $\$ 600$ million lithium ion-battery factory. Mahindra, too, is investing some Rs.600 crore to ramp up its EV division, and is expected to launch electric variants of its popular SUVs, Scorpio and XUV 500. "We believe the auto industry and manufacturers are willing to make this change since most of these have electric car platforms ready," However, it may not be an easy ride. For one, securing longterm battery supplies and developing a battery management system technology that helps recharge batteries are tough. "There are currently only a few large global battery suppliers such as LG Chem, Samsung SDI, and BYD no Indian company seems to be doing this currently.

\section{STATEMENT OF THE PROBLEM}

Introduction of electric vehicle in India will have the massive conversion of fossil fuel to electric vehicles; its impact will be on the automobile sector which will influence the customers to make aware of electric vehicle and customers must be willing to adopt to new technology, 
manufacturer, dealers, bankers and petrol bunks. Due to current environmental problems caused by vehicles, the global aim is to protect our environment and diminish greenhouse gas emissions. However, the launch of Electric Vehicles is still in the initial stage and hesitant. The factors which are importance to customers need to be identified when making product and consumer-related buying decisions related to vehicles. "The Electric Vehicle industry is background begin and electric vehicle is still a small percentage of the general vehicle market but it's starts to reach an inflection point where it can have a really significant impact globally," confine mind the researcher to understand the notice of consumers and their willingness to shop for electric vehicle, the factors considered by customers for electric-vehicle and to realize the shifting environment.

\section{OBJECTIVES OF THE STUDY}

- To discover the level of awareness on electric vehicles along with the users of passenger car and car dealers.

- To know the customers willingness towards electric vehicles.

- To offer suggestions and recommendation.

\section{SCOPE OF THE STUDY}

Today automobile market trend is facing the impact of change technology or transformation with E-vehicle concept. The manufacturer and customers are required to change their mind according to the market trend. As far as the present study is concern it gives attention on the customer's awareness and willingness to buy E-vehicle in the present environment. For the purpose of the study the researcher is able to collect primary data and secondary data from the available resources. It is an attempt to bring out the status of change technology or transformation in manufacturing sector, in consumer awareness and willingness on e-vehicle and more specifically on passenger car. There is a scope of providing valuable input and suggestions which help the e-vehicle market for the sustainable development.

Nowadays automobile market drift is facing the collision of transformation of technology or transformation with E-vehicle concept. The manufacturer and customers are required to change their mind according to the market trend. As far as the present study is concern it gives attention on the customer's awareness and willingness to buy E-vehicle in the present environment. For the aim of the study the researcher is in a position to gather primary data.

\section{METHODOLOGY}

For the purpose of the study, required data have been collected through the primary sources by well designed questionnaire from the sample size of 70 respondents. For the secondary data it has been collected from the sources like books, periodicals, research articles, seminar reports, news papers, study reports of expert committees, departmental publications, plan documents, published dissertations, broucher, pamphlets and advertisements. Period considered for the study is the financial year 2017-2018 and geographical area of the study as far as primary data is concern only at Coimbatore City, Tamil Nadu state.

\section{REVIEW OF LITERATURE}

The following are Literature review to understand more about the significance of the study problem as well as to high light the research gap in the respective field.

Achtnicht,M., Buhler,G.,\&Hermeling,C.(2012).The impact of fuel availability on demand for alternative fuel vehicles. Transportation Research: Transport and Environment,17(3),262269. 
Ziegler,A. (2012). Individual characteristics and stated preferences for alternative energy sources and propulsion technologies in vehicles: A discrete choice analysis for Germany. Transportation Research Part A: Policy and Practice, 46(8),1372-1385.

Woodjack, J., Garas, D., Lentz, A., Turrentine, T., Tal, G., \& Nicholas, M. (2012). Consumerpe rceptions and use of driving distance of electric vehicles. Transportation Research Record: Journal of the Transportation Research Board,2287, 1-8.

Bunce, L., Harris,M.,\&Burgess,M.(2014).Charge up then charge out? Drivers' perceptions and experiences of electric vehicles in the UK. Transportation Research Part A: Policy andPractice,59,278-287.

Glerum, A., Stankovikj, L., \&Bierlaire, M. (2014). Forecasting the demand for electric vehicles: Accounting for attitudes and perceptions. Transportation Science ,48 (4),483- 499.

Wang, M., Chen, W., \& Conzelmann,G.(2014).Incorporating social impact on new

product adoption in choice modeling: A case study in green vehicles. Transportation Research Part D: Transport and Environment, 32,421-434.

Tanaka, M., Ida, T., Murakami, K., \&Friedman, L. (2014). Consumers' willingness to pay for alternative fuel vehicles: A comparative discrete choice analysis between the US and Japan. Transportation Research Part A: Policy and Practice,70, 194-209.

Tamor, M.A., Moraal, P.E., Reprogle, B., \&Milacic, M. (2015). Rapid estimation of electric vehicle acceptance using a general description of driving patterns. Transportation Research Part C: Emerging Technologies,51,136-148.

FanchaoLiao, EricMolinand, Bertvan Wee (2018) Consumer preferences for electric vehicles. Routeledge Taylor Francis Group ISSN: 0144-1647(Print) 1464- 5327(Online) Journal.

SIAM (OCT 2018) Rajan Wadhera, President of SIAM, SIAM makes a big push for electric car. Business line

\section{ANALYSIS AND FINDINGS}

This particular chapter shows the analytical part and findings of the study. For the purpose of statistical analysis, the following tools have been adopted.

- Percentage Analysis

- Chi-Sqaure Analysis

\subsection{Percentage Analysis}

\subsubsection{Level of Awareness on Electric Vehicle}

Table 1 Awareness on elctric vehicle

\begin{tabular}{|c|c|c|}
\hline Level of Awareness & Dealers & Percent \\
\hline Very high awareness & 0 & 0 \\
\hline $\begin{array}{c}\text { High level } \\
\text { awareness }\end{array}$ & 11 & 78.6 \\
\hline Moderately aware & 3 & 21.4 \\
\hline Low awareness & 11 & 78.6 \\
\hline Very low awareness & 0 & 0 \\
\hline Total & 14 & 100.0 \\
\hline
\end{tabular}

The above table indicates that out of 14 dealers taken for the study, $21.4 \%$ of the dealers are moderately aware of electric vehicle and $78.6 \%$ are high awareness about e-vehicle. Hence it was observed majority of $78.6 \%$ of the dealers are highly awareness about e-vehicle. 
Uma Maheswari Sankar, S. Gokilavani and R Rajasekaran

\subsubsection{Level of Agreeability on Pollution and Global Warming}

Table 2 Agreeability on Pollution and Global Warming

\begin{tabular}{|c|c|c|}
\hline Level of agreeability & Dealers & Percent \\
\hline Strongly agree & 3 & 21.4 \\
\hline Agree & 0 & 0 \\
\hline Neutral & 11 & 78.6 \\
\hline Not Agree & 0 & 0 \\
\hline Strongly not agree & 0 & 0 \\
\hline Total & 14 & 100.0 \\
\hline
\end{tabular}

From the above data it has been observed that out of total 14 dealers $78.6 \%$ of the dealers of them are neutral about fossil fuel cars one of the reasons for pollution and $21.4 \%$ of the dealers are strongly agree on cars are reason for pollution and global warming. It is evident from the data analysis that majority of $78.6 \%$ of the dealers are neutral on fossil fuel cars are one of reason for pollution and global warming.

\subsubsection{Level of Agreeability on Pollution and Global Warming}

At present, all family member is possessing one car each for their personal use at the minimum two cars for family. The population of the private car has been increased drastically in the recent era and this may be one of the reasons for pollution made by humans one of the reasons may be by using car on the road. Researcher is interested to know their view and the level of agreeability. Hence, the car users were requested to give their responses on agreeability. The results are presented in the following Table 29 with figures below.

Table 3 Agreeability on Pollution and Global Warming

\begin{tabular}{|c|c|c|}
\hline Agreeability & Car Users & Percent \\
\hline Strongly agree & 156 & 32.2 \\
\hline Agree & 207 & 42.8 \\
\hline Neutral & 73 & 15.1 \\
\hline Disagree & 28 & 5.8 \\
\hline Strongly disagree & 20 & 4.1 \\
\hline Total & 484 & 100 \\
\hline
\end{tabular}

From the above presented empirical data analysis it has been observed from the table that $32.2 \%$ of the car users are strongly agree with reason for pollution is because of fossil fuel cars, $42.8 \%$ are agree with the above information about car, $15.1 \%$ of them are neutral, $5.8 \%$ of them are disagree with the above information about car and $4.1 \%$ of them are strongly disagree with above information about the fossil fuel car.

Thus, it has been clearly identified that most $42.8 \%$ of the car users are agree with reason for the pollution and global warming because of fossil fuel car.

\subsubsection{Level of Agreeability on Electric Vehicle}

Present government and the whole world are in need to convert fossil fuel vehicle to electric vehicle which may help to green environment. Researcher is to know the level of agreeability of the car users on the green environment. The opinion of car users is presented in Table 30 with figures below. 
Table 4 Agreeability on Electric Vehicle

\begin{tabular}{|c|c|c|}
\hline Agreeiability & Car Users & Percent \\
\hline Strongly Agree & 157 & 32.4 \\
\hline Agree & 187 & 38.6 \\
\hline Neutral & 83 & 17.1 \\
\hline Disagree & 33 & 6.8 \\
\hline Strongly Disagree & 24 & 5 \\
\hline Total & 484 & 100.0 \\
\hline
\end{tabular}

The above table indicates that out of 484 car users surveyed, $32.4 \%$ of the car users strongly agree with transformation will help for green environment, $38.6 \%$ of them agree with the above information, $17.1 \%$ are neutral, $6.8 \%$ of them are disagree with above information and $5 \%$ are strongly disagree with the above information. Hence it has been observed most $38.6 \%$ of the car users are agree with transformation of fossil fuel car to electric vehicle will help to green environment.

\subsubsection{Level of Awareness on Electric Vehicle}

Air pollution was the one the pollution which should be notified and it must be eliminate from the environment, for that fossil fuel vehicle to electric vehicle may be one of the first step to reduce the air pollution. Researcher is interested to know whether car users' level of awareness about the electric vehicle. The opinion of car users is presented in Table 28 with figures below.

Table 5 Awareness on Electric Vehicle

\begin{tabular}{|c|c|c|}
\hline Level of Awareness & Car Users & Percent \\
\hline Very high awareness & 86 & 17.8 \\
\hline High & 90 & 18.6 \\
\hline Moderately aware & 223 & 46.1 \\
\hline Low awareness & 56 & 11.6 \\
\hline Very low awareness & 29 & 6.0 \\
\hline Total & 484 & 100.0 \\
\hline
\end{tabular}

From the above table it is inferred that $17.8 \%$ of the car users are very high awareness about electric vehicle, $18.6 \%$ of the car users having high awareness on above information, $46.1 \%$ of them are moderately aware, $11.6 \%$ are low awareness, $6 \%$ of them having very low awareness about electric vehicle. Thus, it has been clearly identified that majority of the car users $46.1 \%$ of the car users are moderately aware of electric vehicle.

\subsubsection{Willingness of the Car Users to Buy Electric Vehicle}

To know the car users opinion on willingness to buy electric vehicle in future rather fossil fuel vehicle to reduce the air pollution. The opinion of car users is presented in Table 32 and figures provide data related to the number of car users who fall under each category willing to buy an electric vehicle in future and their percentage in the total.

The below table indicates that out of 484 car users surveyed, that $79.3 \%$ of the car users are willing purchase electric vehicle in future and $20.7 \%$ of the car users are not willing to purchase. Hence it has been observed majority of the car users $79.3 \%$ of the car users are willing to purchase electric vehicle in future 
Uma Maheswari Sankar, S. Gokilavani and R Rajasekaran

Table 6 Willingness to Buy an Electric Car in Future

\begin{tabular}{|c|c|c|}
\hline Willingness & Car Users & Percent \\
\hline Willing to buy & 384 & 79.3 \\
\hline Not willing to buy & 100 & 20.7 \\
\hline Total & 484 & 100.0 \\
\hline
\end{tabular}

\subsection{Chi-Square Tests}

\subsubsection{Age Group and Willingness to Buy Electric Vehicle}

Chi-square test has been applied to find whether there is any significant relationship between age group and willingness to electric vehicle in future.

Null Hypothesis: There is no significance relationship between the age group and willingness to buy e-vehicle in future.

Alternative hypothesis: There is a significance relationship between the age group and willingness to buy e-vehicle in future.

Table 7 Association Between Age Group \& Willingness to Buy An E- Vehicle In future

\begin{tabular}{|c|c|c|c|c|c|c|}
\hline \multirow[t]{2}{*}{ Age Group } & \multicolumn{6}{|c|}{ State Your Willingness to Buy An E- Vehicle In Future Total|Percentage } \\
\hline & Willing to & ercentage & Not Willing & rcent & & \\
\hline 21-30 Years & 113 & $30 \%$ & 35 & 35 & & $31 \%$ \\
\hline 31-40 Years & 124 & $32 \%$ & 19 & 19 & & $29 \%$ \\
\hline 41-50 Years & 94 & $24 \%$ & 28 & 28 & & $25 \%$ \\
\hline Above 50 Years & 53 & $14 \%$ & 18 & 18 & 71 & $15 \%$ \\
\hline Total & 384 & 100 & 100 & 100 & & 100 \\
\hline
\end{tabular}

Chi-square test was applied to find out whether there is significant relationship between the age group and willingness to buy electric vehicle in future. Above table represents the different age group and state of willingness to buy an e-vehicle.

Table 8

\begin{tabular}{|c|l|c|c|}
\hline \multicolumn{4}{|c|}{ Chi-Square Tests } \\
\hline Chi-Square Tests & Value & df & Sig. \\
\hline Pearson Chi-Square & $6.893^{\mathrm{a}}$ & 3 & .075 \\
\hline
\end{tabular}

The calculated chi square value is having the high table value at $5 \%$ level of significance. Hence it is inferred that there is an evidence to suggest a relationship between age group and willingness to buy electric car hence the null hypothesis is accepted and the alternative hypothesis is rejected.

\subsubsection{One of The Reason for The Pollution and Global Warming and Transformation Will Help Green Environment}

Chi-square test has been applied to find whether there is any significant relationship between one of the reasons for the pollution/global warming and transformation to e- vehicle will help for green environment.

Null Hypothesis: There is no significance relationship between the fossil fuel cars are one of the reasons for the pollution/global warming and transformation to e-vehicle will help for green environment.

Alternative hypothesis: There is a significance relationship between the fossil fuel cars are one of the reasons for the pollution/global warming and transformation to e-vehicle will help for green environment. 
Chi-square test was applied to find out whether there is significant relationship between the fossil fuel cars are one of the reasons for the pollution $\&$ for global warming and transformation to e-vehicle will help for green environment. Below table represents crosstab.

Table 9

\begin{tabular}{|c|c|c|c|c|c|c|c|}
\hline & & $\begin{array}{r}\text { The } \\
\text { Cars in To El }\end{array}$ & $\begin{array}{r}\text { ransfor } \\
\text { trical C } \\
\text { Env }\end{array}$ & $\begin{array}{l}\text { nation of } \\
\text { ar Will I } \\
\text { ironmen }\end{array}$ & $\begin{array}{l}\text { f Fossil F } \\
\text { Help Us f } \\
\text { t }\end{array}$ & el A Green & TOTAL \\
\hline & & Strongly agree & Agree & Neutral I & Disagree & $\begin{array}{l}\text { Strongly } \\
\text { disagree }\end{array}$ & \\
\hline & Strongly agree & 105 & 32 & 14 & 2 & 3 & 156 \\
\hline Fossil Fuel Cars Are the one of & Agree & 42 & 125 & 32 & 5 & 3 & 207 \\
\hline $\begin{array}{c}\text { The Reason for the Pollution / } \\
\text { Global Warming }\end{array}$ & Neutral & 5 & 27 & 30 & 10 & 1 & 73 \\
\hline & Disagree & 5 & 2 & 6 & 12 & 3 & 28 \\
\hline & Strongly disagree & 0 & 1 & 1 & 4 & 14 & 20 \\
\hline TOTAL & & 157 & 187 & 83 & 33 & 24 & 484 \\
\hline
\end{tabular}

Table 10

\begin{tabular}{|c|c|c|c|}
\hline \multicolumn{4}{|c|}{ Chi-Square Tests } \\
\hline Chi-Square Tests & Value & df & Sig. \\
\hline Pearson Chi- Square & $4.343 \mathrm{E}^{\mathrm{a}}$ & 16 & $.000^{*}$ \\
\hline
\end{tabular}

From the above table a chi-squared test gave a p-value of $p<0.05$ so there is a strong evidence to suggest a relationship between the fossil fuel cars are one of the reasons for the pollution/global warming and transformation to e-vehicle will help for green environment.

Hence null hypothesis is accepted and the alternative hypothesis is rejected.

\subsubsection{One of The Reason for The Pollution and Global Warming and Awareness About Electric Vehicle}

Chi-square test has been applied to find whether there is any significant relationship between one of the reasons for the pollution/global warming and awareness about e- vehicle.

Null Hypothesis: There is no significance relationship between the fossil fuel cars are one of the reasons for the pollution/global warming and awareness about e-vehicle.

Alternative hypothesis: There is a significance relationship between the fossil fuel cars are one of the reasons for the pollution/global warming and awareness about e-vehicle.

Chi-square test was applied to find out whether there is significant relationship between the fossil fuel cars are one of the reasons for the pollution/global warming and awareness about evehicle. Below table represents crosstab.

The above table represents chi-square test between the fossil fuel cars are one of the reason for the pollution/global warming and awareness about e-vehicle 
Table 11

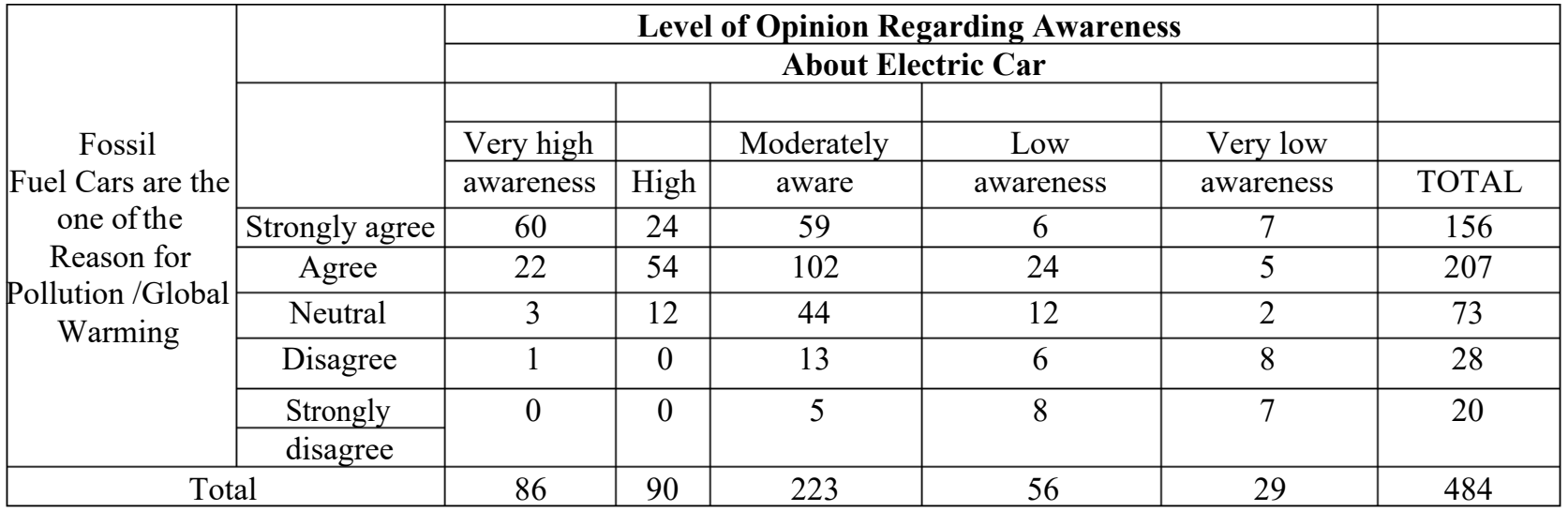

Table 12

\begin{tabular}{|c|c|c|c|}
\hline \multicolumn{4}{|c|}{ Chi-Square Tests $^{|c|}$} \\
\hline Chi-Square Tests & Value & df & Sig. \\
\hline Pearson Chi-Square & $1.661 \mathrm{E}^{\mathrm{a}}$ & 16 & .000 \\
\hline
\end{tabular}

A chi-squared test gave a $p$-value of $p<0.05$ so there is a strong evidence to suggest a relationship between the fossil fuel cars are one of the reasons for the pollution/global warming and awareness about e-vehicle. Hence null hypothesis is accepted and the alternative hypothesis is rejected.

\subsubsection{Transformations of Fossil Fuel Cars in To Electrical Car Will Help for A Green Environment and Awareness About E-Vehicle.}

Chi-square test has been applied to find whether there is any significant relationship between transformations of fossil fuel cars in to electrical car will help for a green environment and awareness about e-vehicle.

Null Hypothesis: There is no significance relationship between the transformation of fossil fuel cars to e-vehicle will help for a green environment and awareness about e-vehicle.

Alternative hypothesis: There is a significance relationship between the transformation of fossil fuel cars to e-vehicle will help for a green environment and awareness about e-vehicle.

Chi-square test was applied to find out whether there is significant relationship between transformations of fossil fuel cars in to electrical car will help for a green environment and awareness about e-vehicle. It is clear from the below table represents crosstab

Table 13

\begin{tabular}{|c|c|c|c|c|c|c|c|}
\hline & \multicolumn{6}{|c|}{ Level of Opinion regarding Awareness about Electric Car } & \multirow[b]{2}{*}{ Total } \\
\hline \multirow{6}{*}{$\begin{array}{l}\text { Transformation of fossil } \\
\text { fuel cars in to electrical car } \\
\text { will help us for a green } \\
\text { environment }\end{array}$} & & $\begin{array}{c}\text { very high } \\
\text { awareness }\end{array}$ & $\begin{array}{c}\text { high } \\
\text { awareness }\end{array}$ & $\begin{array}{c}\text { moderately } \\
\text { aware }\end{array}$ & $\begin{array}{c}\text { low } \\
\text { awareness }\end{array}$ & $\begin{array}{l}\text { very low } \\
\text { awareness }\end{array}$ & \\
\hline & $\begin{array}{l}\text { strongly } \\
\text { agree }\end{array}$ & 63 & 27 & 52 & 7 & 8 & 157 \\
\hline & agree & 16 & 43 & 107 & 18 & 3 & 187 \\
\hline & neutral & 5 & 15 & 46 & 14 & 3 & 83 \\
\hline & disagree & 2 & 3 & 13 & 11 & 4 & 33 \\
\hline & $\begin{array}{l}\text { strongly } \\
\text { disagree }\end{array}$ & 0 & 2 & 5 & 6 & 11 & 24 \\
\hline total & & 86 & 90 & 223 & 56 & 29 & 484 \\
\hline
\end{tabular}


Table 14

\begin{tabular}{|c|c|c|c|}
\hline \multicolumn{4}{|c|}{ Chi-Square Tests } \\
\hline Chi-Square Tests & Value & df & Sig. \\
\hline Pearson Chi-Square & $1.868 \mathrm{E} 2^{\mathrm{a}}$ & 16 & .000 \\
\hline
\end{tabular}

A chi-squared test gave a $p$-value of $p<0.05$ so there is a strong evidence to suggest a relationship between the transformations of fossil fuel cars in to electrical car will help for a green environment and awareness about e-vehicle. Hence null hypothesis is accepted and the alternative hypothesis is rejected.

\section{SUGGESTIONS}

The following are suggestions of the customers those who are using fossil fuel car for their regular purpose and plan to go for electric vehicle in the near future.

- It is suggested that the government need to take appropriate policy in order to encourage the production and usage of e-vehicle.

- Manufacturer of e-vehicle requested to approach the government in order to avail incentives and privileges for e-vehicle.

- It is also suggested to the government that to generate and supply adequate electricity power to encourage and manage e-vehicle.

- The customers of the study suggested that the charging station and other infrastructure for e-vehicle need to be established with the concept of accessibility and affordability.

- It is also suggested that to safeguard the environment for which the eco-friendly evehicle need to be introduced and encourage for the sustainable development.

\section{CONCLUSION}

Change technology is the order of the day, the present ruling Government is focusing on the development in the name of digital India policy, Transformation, Artificial Intelligence, Automation etc. As far as this particular study is concern with the customers, those who are using fossil fuel car are favouring for transformation from conventional technology to modern technology, it clearly shows that the perception of the customers towards e-vehicle is favourable and encourage able. The study also reveals that the age group between 40-50 and above 50 are willing to go foe e-vehicle and also, they are supporting e-vehicle in order to safeguard the nature and environment. the statistical tools used various analysis shows the encouraging trend for e-vehicle and its change technologies. From the study it is clearly understood that customer's awareness and willingness to buy e-vehicle is favourable and it is influenced by the establishment of adequate charging stations, availability of electricity, connectivity, Government incentives, Banks support and services. According to the Government policy there is a proposal to convert the existing fossil fuel vehicle to e-vehicle by 2030 . Hence the manufactures, marketers, bankers and customers need to make their mind in order to accept the change technology and transformation for e-vehicle and more specifically about the passenger car market. The study also throws a light on for their research opportunities in the same field of e-vehicle in order to understand the present environment. 


\section{REFERENCES}

[1] Keneeth lebeau. (2013). Consumer attitudes towards battery electric vehicles: A large-scale survey. International journal of electric and hybrid.

[2] Shukla, P.R.; Dhar, Subash; Pathak, Minal; Bhaskar, Kalyan(2014) Electric Vehicles Scenarios and a Roadmap for India. UNEP DTU Partnership.

[3] Kashyap L. Mokariya, Varsha A. Shah, Makarand M. Lokhande (2015) Feasibility and Penetration of Electric Vehicles in Indian Power Grid. International Scholarly and Scientific Research \& Innovation 9(2) 2015 scholar. waset.org/1307-6892/10000434.

[4] ATMACA, Erkan(2015). Turkish Journal of Electrical Engineering \& Computer Sciences, Vol. 23 Issue 4, p1142-1158, 20p; DOI: 10.3906/elk-1212-37, Database: OmniFile Full Text Mega (H.W. Wilson)

[5] Sarma, Ranendra(2016) Assessment of Investment worthiness of Hydro Electric Projects water and energy international Volume: 58r Issue: 11 Pages: 42-51 Published: Feb 2016 Print ISSN: 0974-4207 Online ISSN: 0974-4711.

[6] Arora Nitish (2017) Source: Making resource-efficient batteries for electric vehicles Volume: 14 Issue: 2 Pages: 83-94 Published: Sep 2017 Print ISSN: 0975-7554 Online ISSN: 0974-0929 DEVELOPMENT Volume: 14 Issue: 2 Pages: 83-94.

[7] Danielis, Romeo; Giansoldati, Marco; Rotaris, Lucia. Energy Policy, Aug2018, Vol. 119, p268281, 14p; DOI: 10.1016/j.enpol.2018.04.024, Database: OmniFile Full Text Mega (H.W. Wilson) In order to evaluate the current and future prospects of electric cars' in Italy.

[8] HOWELL, JOHN. People Management (Oct2018), p42-46, 4p, Database: Omni File Full Text Mega (H.W. Wilson) The article features several vehicles which are ideal as a business benefit, including the Toyota Prius 1.8 VVT-I Plug-In Hybrid Business Edition Plus, the Audi Q7 3.0 TDI 218 Quattro SE

[9] The Society of Manufacturers of Electric Vehicles (Smev) https://www.smev.in/

[10] Society of Indian automobile manufacturers (siam), available: www.siamindia.com. 